\title{
PERBANYAKAN TANAMAN HIAS AIR TAWAR Alternanthera reinickii DAN Ludwigia sp SECARA IN VITRO GUNA MENDUKUNG AQUASCAPE
}

\author{
Ruhil Irawan", Rossa Yunita ${ }^{* *}$, Media Fitri Isma N.**, Benny Diyah M. \\ *Program Studi Budidaya Perairan Fakultas Perikanan Universitas Pekalongan \\ ***alai Perikanan Budidaya Ikan Hias Depok
}

\begin{abstract}
Water plants are the hydrophytic plants that occupy the highest ecology in aquatic environments. Alternanthera reinickii and Ludwigia sp are freshwater ornamental plants that are in great demand of aquascape lovers market. Plant tissue culture is a technique to grow the growing parts of plants, either in the form of cells, tissues or organs in aseptic conditions in vitro. The study was conducted on 15 January to 15 April 2018, at the Center for Biotechnology Research and Bogor Agricultural Genetic Resources. This research is done by using experiment method in laboratory. From the results of research on ornamental plants Alternanthera reinickii data obtained on the leaf paremeter giving regeneration substances grow the type of BAP with a concentration of $0.3 \mathrm{ml} / \mathrm{l}$ capable of producing the largest number of leaves. In shoot height parameters obtained the highest results using Kinetin treatment concentration $0.1 \mathrm{ml} / l$. In the parameter of shoot number of growth regulator substances $B A P$ concentration of $0.5 \mathrm{ml} / \mathrm{l}$ resulted in the largest number of shoots. In the parameter of the root number of BAP treatment with the concentration of $0.3 \mathrm{ml} / \mathrm{l}$ shows the largest number of roots. In contrast to the ornamental plant Ludwigia sp BAP treatment of $0.1 \mathrm{ml} / \mathrm{l}$ concentration is able to produce the highest number of leaves In the parameters of shoot BAP treatment at low concentrations of $0.1 \mathrm{ml} / \mathrm{l}$. on the parameters of BAP treatment buds concentration of $0.3 \mathrm{ml} / \mathrm{l}$ resulted in the largest number of shoots. In the parameter of the root number of BAP treatment, the concentration of $0.1 \mathrm{ml} / \mathrm{l}$ showed the highest number of roots.
\end{abstract}

Keywords: Alternanthera reinickii, Ludwigia sp, Tissue culture, BAP, Kinetin

\section{PENDAHULUAN}

Tanaman air merupakan, tanaman hidrofit yang menempati ekologi tertinggi di dalam lingkungan perairan. Manfaat tanaman hias air tawar untuk memperindah akuarium juga dapat membantu meningkatkan keindahan dan kesehatan ikan hias karena dapat mengurangi stress ikan dan menjadi media perkembangan bagi ikan hias dan membantu meningkatkan kadar oksigen di dalam air, selain manfaat tanaman air sebagai obat-obatan, bahan kosmetik, dan bahan industri. Alternanthera reinickii dan Ludwigia sp adalah tanaman hias air tawar yang banyak diminati pasar pecinta aquascape. Pembudidaya untuk kedua jenis tanaman ini masih tergolong langka, karena masyarakat belum memahami cara budidaya tanaman hias air secara efektif dan efisien. Sehingga perlu dilakukannya perbanyakan pada kedua jenis tanaman hias air tawar jenis Alternanthera reinickii dan Ludwigia sp. Kultur jaringan tanaman merupakan teknik menumbuh kembangkan bagian tanaman, baik berupa sel, jaringan atau organ dalam kondisi aseptik secara in vitro. Teknik ini dicirikan oleh kondisi aseptik, penggunaan media kultur buatan dengan kandungan nutrisi lengkap dan penambahan zat pengatur tumbuh (ZPT). Serta kondisi ruang kultur yang suhu dan pencahayaan terkontrol (Yustina, 2003).

Zat pengatur tumbuh yang sering digunakan untuk menginduksi pertumbuhan adalah golongan Sitokinin dimana pada penelitian ini jenis yang digunakan adalah Kinetin dan BAP (Santoso dan Nursandi, 2003). Salah satu jenis Sitokinin yang sering dipakai 
dalam kultur jaringan adalah BAP (6-benzylaminopurrine) yang merupakan salah satu Sitokinin sintetik yang aktif dan daya merangsangnya lebih lama karena tidak mudah dirombak oleh enzim di dalam tanaman (George dan Sherrington, 1984). Menurut Noggle dan Fritz (1983) BAP memiliki struktur yang mirip dengan Kinetin dan juga aktif dalam pertumbuhan dan poliferasi kalus.

Penelitian ini bertujuan untuk mencari jenis Sitokinin dan kosentrasi yang tepat terhadap multipikasi pertumbuhan tanaman hias air tawar Alternanthera reinickii dan Ludwigia sp secara in vitro.

\section{MATERI DAN METODE PENELITIAN}

Penelitian dilaksanakan pada tanggal 15 Januari sampai dengan 15 April 2018, di Balai Besar Penelitian Bioteknologi dan Sumberdaya Genetik Pertanian Bogor.

Penelitian dilaksanakan menggunakan Rancangan acak lengkap (RAL) faktorial 2 faktor yaitu : 4 ulangan untuk tanaman hias air Alternanthera reinickii serta 2 perlakuan dan 3 ulangan untuk tanaman hias air tawar Ludwigia sp. Faktor 1 adalah jenis Sitokinin yaitu BAP dan Kinetin dan faktor 2 adalah konsentrasi $(0,1 \mathrm{ml} / 1 ; 0,3 \mathrm{ml} / 1 ; 0,5 \mathrm{ml} / \mathrm{l})$. Pengambilan data dilakukan berdasarkan pengamatan eksplan uji yang telah ditempatkan pada media kontrol dan botol media yang ditambah zat pengatur tumbuh. Sesuai penanaman dipantau perkembangannya setiap tujuh hari, selama 4 minggu. Parameter perubahan diamati dalam penelitian ini adalah jumlah daun, tinggi tunas, jumlah tunas, dan jumlah akar dilakukan setiap seminggu sekali.

\section{HASIL DAN PEMBAHASAN}

\subsection{Alternanthera reinickii}

\subsubsection{Jumlah daun}

Pengambilan hasil data dilakukan pada minggu ke 4. Data hasil pengamatan rata-rata jumlah daun disajikan pada tabel 1.

Tabel 1. Jumlah daun Alternanthera reinickii pada minggu ke 4

\begin{tabular}{lllll}
\hline \multirow{2}{*}{ Sitokinin } & \multicolumn{4}{c}{ Konsentrasi ml/1 } \\
\cline { 2 - 5 } & \multicolumn{1}{c}{0} & 0,1 & 0,3 & \multicolumn{1}{c}{0,5} \\
\hline \multirow{3}{*}{ BAP } & $19,25 \pm$ & $17,5 \pm$ & $25 \pm$ & $21,75 \pm$ \\
& 2,21 & 1,91 & 5,35 & 2,21 \\
Kin & $19,25 \pm$ & $22 \pm$ & $23 \pm$ & $18,75 \pm$ \\
& 2,21 & 2,24 & 4,24 & 1,25 \\
\hline
\end{tabular}

Sumber : Penelitian 2018

Pada tabel 1 mengenai data rata-rata jumlah daun Alternanthera reinickii menunjukkan bahwa zat pengatur tumbuh golongan Sitokinin jenis BAP dengan konsentrasi $0,3 \mathrm{ml} / \mathrm{l}$ mampu menghasilkan jumlah daun terbanyak. Dengan peningkatan produksi klorofil pada tanaman mengakibatkan proses fotosistetis juga meningkat sehingga akan terbentuk senyawa organik seperti karbohidrat untuk proses pembentukan daun (yustina, 2003). Berbeda dengan pemberian zat pengatur tumbuh jenis BAP dengan konsentrasi $0,1 \mathrm{ml} / \mathrm{l}$ memberikan hasil pertumbuhan daun paling rendah. 


\subsubsection{Tinggi tunas}

Pertambahan tinggi tunas dapat dilihat dari tabel 2.

Tabel 2. Tinggi tunas Alternanthera reinickii pada minggu ke 4.

\begin{tabular}{lllll}
\multirow{2}{*}{ Sitokinin } & \multicolumn{4}{c}{ Konsentrasi $\mathrm{ml} / 1$} \\
\cline { 2 - 5 } & \multicolumn{1}{c}{0} & 0,1 & 0,3 & 0,5 \\
\hline \multirow{3}{*}{ BAP } & $1,98 \pm$ & $2,12 \pm$ & $2,31 \pm$ & $2,35 \pm$ \\
& 0,32 & 0,18 & 0,41 & 0,25 \\
\multirow{2}{*}{ Kin } & $1,98 \pm$ & $2,42 \pm$ & $2,15 \pm$ & $2,4 \pm$ \\
\hline Sumber : Penelitian & 0,2018 & 0,27 & 0,09 \\
\hline
\end{tabular}

Sumber : Penelitian 2018

Berdasarkan pengukuran tinggi tunas tanaman Alternanthera reinickii pada minggu ke 4, Pada kedua jenis Sitokinin kecenderungan tinggi tunas pada perlakuan Kinetin konsentrasi 0,1 ml/l eksplan sudah mampu tumbuh, sehingga tidak membutuhkan Sitokinin kosentrasi yang tinggi. Seperti yang dinyatakan oleh Santoso dan Nursandi (2003) bahwa zat pengatur tumbuh adalah senyawa organik maupun anorganik yang hanya dibutuhkan tanaman dalam konsentrasi yang sedikit. Pertumbuhan tinggi tunas paling lambat menggunakan kontrol atau MS-0, hal ini karena kandungan nutrisi pada MS-0 kurang mencukupi untuk pertumbuhan tinggi tunas. Sesuai dengan pendapat Sriyani dan Wijayani (1994) bahwa tanpa pemberian zat pengatur tumbuh di dalam media, maka pertumbuhan terhambat bahkan mungkin tidak tumbuh.

3.1.3. Jumlah tunas

Pertambahan jumlah tunas dapat dilihat pada tabel 3.

Tabel 3. Jumlah tunas Alternanthera reinickii pada minggu ke 4

\begin{tabular}{cllll}
\hline \multirow{2}{*}{ Sitokinin } & \multicolumn{4}{c}{ Konsentrasi $\mathrm{ml} / \mathrm{l}$} \\
\cline { 2 - 5 } & \multicolumn{1}{c}{0} & \multicolumn{1}{c}{0,1} & \multicolumn{1}{c}{0,3} & 0,5 \\
\hline \multirow{3}{*}{ BAP } & $3,25 \pm$ & $3,62 \pm$ & $3,87 \pm$ & $4,12 \pm$ \\
& 0,5 & 0,47 & 0,85 & 0,85 \\
\multirow{2}{*}{ Kin } & $3,25 \pm$ & $4 \pm$ & $4 \pm$ & \\
\hline \multicolumn{4}{l}{ Sumber : Penelitian 2018}
\end{tabular}

Pada penelitian ini pemberian zat pengatur tumbuh BAP konsentrasi 0,5 $\mathrm{ml} / \mathrm{l}$ menujukkan hasil jumlah tunas terbanyak. Pada penelitian lain yang dilakukan Nursyamsi et al. , (2007) di mana penggunaan BAP konsentrasi 0,5 $\mathrm{ml} / \mathrm{l}$ yang diberikan pada tanaman jati muna memberikan efek signifikan untuk pertumbuhan tunas. Berbeda pada perlakuan Kinetin konsentrasi 0,5 ml/1 menghasilkan jumlah tunas terendah (Tabel 3). Hal ini diduga penambahan konsentrasi terlalu tinggi akan menghambat pertumbuhan tunas.

\subsubsection{Jumlah akar}

Pertumbuhan akar dapat dilihat dari tabel 4 berikut ini. 
Tabel 4. Jumlah akar Alternanthera reinickii pada minggu ke 4

\begin{tabular}{lllll}
\hline \multirow{2}{*}{ Sitokinin } & \multicolumn{4}{c}{ Konsentrasi $\mathrm{ml} / \mathrm{l}$} \\
\cline { 2 - 5 } & \multicolumn{1}{c}{0} & 0,1 & 0,3 & 0,5 \\
\hline \multirow{3}{*}{ BAP } & $13,62 \pm$ & $15,37 \pm$ & $23,5 \pm$ & $21,12 \pm$ \\
& 3,56 & 3,52 & 3,93 & 3,25 \\
\multirow{2}{*}{ Kin } & $13,62 \pm$ & $18,87 \pm$ & $22,25 \pm$ & $17,87 \pm$ \\
\hline Sumber : P & 3,56 & 2,78 & 4,44 & 4,69 \\
\hline
\end{tabular}

Sumber : Penelitian 2018

Dilihat dari tabel 4, setiap variasi pemberian konsentrasi memicu pertumbuhan akar yang berbeda. Pada penelitian ini perlakuan BAP dengan konsentrasi $0,3 \mathrm{ml} / \mathrm{l}$ menunjukkan jumlah akar terbanyak. Hal itu tidak sama dengan pemberian Sitokinin berupa Kinetin dan BAP dengan konsentrasi 0,5 $\mathrm{ml} / \mathrm{l}$ menujukkan penurunan pada jumlah akar diduga Sitokinin endogen di dalam eksplan sudah mencukupi untuk pertumbuhan akar sehingga Sitokinin eksogen yang ditambahkan terlalu tinggi pada media kultur tidak dapat mempercepat pertumbuhan akar lebih tinggi, bahkan cenderung memperlambat terbentuknya akar. Hal ini diperkuat oleh George dan Sherrington (1984) bahwa Sitokinin berkonsentrasi tinggi $(0,5-10 \mathrm{ml} / \mathrm{l})$ umumnya menghambat terbentuknya akar.

\subsection{Ludwigia sp}

3.2.1. Jumlah daun

Respon pertumbuhan jumlah daun pada Ludwigia sp dapat dilihat dari tabel 5 .

Tabel 5. Jumlah daun Ludwigia sp pada minggu ke 4

\begin{tabular}{lllll}
\hline \multirow{2}{*}{ Sitokinin } & \multicolumn{4}{c}{ Konsentrasi $\mathrm{ml} / \mathrm{l}$} \\
\cline { 2 - 5 } & \multicolumn{1}{c}{0,1} & \multicolumn{1}{c}{0,3} & \multicolumn{1}{c}{0,5} \\
\hline \multirow{3}{*}{ BAP } & $14 \pm 4$ & 1,15 & $26 \pm 6$ & 3,05 \\
& & $17,33 \pm$ & $16 \pm$ & $16,67 \pm$ \\
\multirow{2}{*}{ Kin } & $14 \pm 4$ & 2,30 & 3,46 & 1,15 \\
\hline
\end{tabular}

Sumber : Penelitian 2018

Berdasarkan tabel 5 pemberian Sitokinin dengan konsentrasi tinggi pada perlakuan BAP dan Kinetin menunjukkan penurunan jumlah daun. Perlakuan BAP konsentrasi 0,1 ml/l mampu menghasilkan jumlah daun terbanyak. Berbeda dengan Kinetin konsentrasi $0,1 \mathrm{ml} / \mathrm{l}$ pertumbuhan jumlah daun tidak sebanyak yang dihasilkan pada perlakuan BAP. Tingginya konsentrasi menyebabkan penurunan jumlah daun. Diduga Sitokinin endogen di dalam eksplan sudah mencukupi untuk pertambahan daun sehingga Sitokinin eksogen yang ditambahkan terlalu tinggi tidak dapat mempercepat pertumbuhan daun lebih tinggi, bahkan mampu memperlambat terbentuknya daun baru. Jumlah daun terendah pada perlakuan MS-0 atau kontrol. Jumlah daun yang dihasilkan hanya $14 \pm 4$. Diduga tanpa pemberian zat pengatur tumbuh kurang optimal dalam perbanyakan jumlah daun. 


\subsubsection{Tinggi tunas}

Pengamatan tinggi tunas dilakukan pada minggu ke 4. dapat dilihat pada tabel ke 6 .

Tabel 6. Tinggi tunas Ludwigia sp pada minggu ke 4

\begin{tabular}{|c|c|c|c|c|}
\hline \multirow{2}{*}{ Sitokinin } & \multicolumn{4}{|c|}{ Konsentrasi ml/l } \\
\hline & 0 & 0,1 & 0,3 & 0,5 \\
\hline \multirow{3}{*}{ BAP } & $3,17 \pm$ & $3,53 \pm$ & $2,67 \pm$ & $2,17 \pm$ \\
\hline & 0,11 & 0,37 & 0,70 & 2,65 \\
\hline & $3,17 \pm$ & $3,27 \pm$ & $2,57 \pm$ & $2,1 \pm$ \\
\hline Kin & 0,11 & 0,46 & 0,60 & 0,81 \\
\hline
\end{tabular}

Berdasarkan tabel 6, Tinggi tunas paling optimum dengan perlakuan BAP dan Kinetin pada konsentrasi rendah $0,1 \mathrm{ml} / \mathrm{l}$. Hal ini diduga secara fisiologis kandungan Sitokinin endogen pada tumbuhan sudah mampu untuk pertumbuhan tinggi tunas sehingga penambahan konsentrasi tinggi akan menghambat pertumbuhan tinggi tunas.

Tinggi tunas terendah pada perlakuan Kinetin konsentrasi $0,5 \mathrm{ml} / \mathrm{l}$. Diduga pertumbuhan tinggi tunas tidak memerlukan Sitokinin eksogen terlalu tinggi karena kandungan sitokinin endogen dalam jaringan sudah mencukupi untuk pertumbuhan tinggi tunas.

3.2.3. Jumlah tunas

Pengamatan jumlah tunas dilakukan pada minggu ke 4. Dapat dilihat pada tabel ke 7 .

Tabel 7. Jumlah tunas Ludwigia sp dilihat pada minggu ke 4.

\begin{tabular}{|c|c|c|c|c|}
\hline \multirow{2}{*}{ Sitokinin } & \multicolumn{4}{|c|}{ Konsentrasi ml/L } \\
\hline & 0 & 0,1 & 0,3 & 0,5 \\
\hline BAP & $\begin{array}{l}2,33 \pm \\
1,15\end{array}$ & $\begin{array}{l}5,33 \pm \\
0,57\end{array}$ & $\begin{array}{l}6,33 \pm \\
1,52\end{array}$ & $\begin{array}{l}4,67 \pm \\
0,57\end{array}$ \\
\hline Kin & $\begin{array}{l}2,33 \pm \\
1,15\end{array}$ & $\begin{array}{l}3,33 \pm \\
0,57\end{array}$ & $\begin{array}{l}2,67 \pm \\
0,57\end{array}$ & $3 \pm 0$ \\
\hline
\end{tabular}

Sumber : Penelitian 2018

Tunas paling banyak dihasilkan pada perlakuan BAP konsentrasi 0,3 $\mathrm{ml} / \mathrm{l}$ yaitu $6,33 \pm 1,52$. Hasil penelitian tersebut menunjukkan bahwa peningkatan jumlah konsentrasi pada taraf tertentu mampu mempercepat pertumbuhan tunas. BAP secara eksogen dibutuhkan untuk multipikasi tunas karena BAP dalam kultur jaringan mempunyai peran fisiologis untuk memacu pertumbuhan tunas (Marlin, 2009). Kinetin konsentrasi 0,3 ml/l menghasilkan jumlah tunas berbeda dibanding BAP, jumlah tunas yang dihasilkan lebih rendah yaitu $2,67 \pm 0,57$. 


\subsubsection{Jumlah akar}

Rata-rata pertumbuhan akar yang di amati pada akhir minggu penelitian yaitu minggu ke 4 dilihat pada tabel 8 .

Tabel 8. Pertumbuhan akar tanaman air tawar Ludwigia sp.

\begin{tabular}{llrll}
\hline \multirow{2}{*}{ Sitokinin } & \multicolumn{4}{c}{ Konsentrasi ml/l } \\
\cline { 2 - 5 } & & 0,1 & 0,3 & 0,5 \\
\hline \multirow{3}{*}{ BAP } & $25,67 \pm$ & $28,67 \pm$ & $23 \pm$ & $19,67 \pm$ \\
& 2,51 & 5,68 & 4,35 & 8,80 \\
\multirow{2}{*}{ Kin } & $25,67 \pm$ & & $22,67 \pm$ & $26,33 \pm$ \\
\hline \multicolumn{2}{l}{ Sumber : Penelitian 2018} & & &
\end{tabular}

Pemberian perlakuan BAP konsentrasi $0,1 \mathrm{ml} / \mathrm{l}$ menujukkan hasil jumlah akar terbanyak. Jumlah daun terendah pada perlakuan BAP konsentrasi 0,5 ml/l. Diduga bahwa perlakuan BAP konsentrasi tinggi lebih banyak digunakan untuk multipikasi tunas dari pada pembentukkan akar. Penelitian lain pada eksplan jahe penambahan BAP dalam konsentrasi tinggi menyebabkan eksplan lebih terfokus pada multipikasi tunas sehingga menyebabkan terhambatnya eksplan membentuk akar (Marlin, 2005).

\section{KESIMPULAN DAN SARAN}

\subsection{Kesimpulan}

Perbanyakan tanaman hias air tawar Alternanthera reinickii dan Ludwigia sp secara in vitro dengan perlakuan Sitokinin jenis BAP dan Kinetin serta pemberian konsentrasi yang berbeda menghasilkan hasil berbeda pada setiap parameter yang diamati.

\subsection{Saran}

Saran yang dapat diberikan dari hasil penelitian adalah perlu dilakukan penelitian lanjutan menggunakan Sitokinin dan kombinasi Auksin dengan dosis yang berbeda sebagai pertumbuhan akar yang lebih optimal.

\section{DAFTAR PUSTAKA}

Elfiani dan Jakoni. 2015. Sterilisasi Eksplan dan Subkultur Anggrek, Sirih Merah, dan Krisan Pada Perbanyakan Tanaman Secara In Vitro. Jurnal Dinamika Pertanian. Hal 117-124.

George, E.F. dan P.D. Sherrington. 1984. Plant Propagation by Tissue Culture. Exegetics Limited. England.

Gunawan, L.W.1987. Teknik Kultur Jaringan Tumbuhan. Pusat Antar Universitas (PAU), Bioteknologi. IPB. Bogor.

Karyadi, A. K dan Buchory. 2008. Pengaruh Komposisi Media Dasar, Penambahan BAP Terhadap Induksi Tunas Bawang Merah. Jurnal Holtikultura. 
Lestari, E.G. 2011. Peran Zat Pengatur Tumbuh Dalam Perbanyakan Tanaman Melalui Kultur Jaringan. Jurnal Agro Biogen. Hal 118-128

Lina, Rossa Lina., Ratnasari, Evie., dan Wahyono, Rahmad. 2013. Pengaruh 6benzyleaminopurine (BAP) dan 6-furfurytaminopurine (Kinetin) Pada Media MS Terhadap Pertumbuhan Eksplan Ujung Apikal Tanaman Jati Secara In Vitro. Lentera Bio. Hal 57-61.

Mahdi, Imam., Syafi'i, Wan., dan Agustiani, Suci. 2015. Kultur Jaringan Jeruk Kasturi Dengan Menggunakan Hormon Kinetin Dan NAA. Jurnal Dinamika Pertanian. Hal 3744.

Marlin. 2009. Mikropopagasi Jahe (Zingiber Officinale Rosc) Sebagai Bahan Fitofarmaka Potensial.

Marlin. 2005. Regenerasi In Vitro Planlet Jahe Bebas Penyakit Layu Bakteri Pada Beberapa Taraf Konsentrasi BAP dan NAA. Jurnal Ilmu Pertanian Indonesia. Hal 8-14.

Nursyamsi., Suhartati., dan Qudus T. Abd. 2007. Pengaruh Zat Pengatur Tumbuh Pada Perbanyakan Tanaman Jati Muna Secara Kultur Jaringan. Jurnal Penelitian Hutan dan Konservasi Alam. Hal 385-390.

Santoso, U. dan Nursandi, F. 2003. Kultur Jaringan Tanaman. Penerbit Universitas Muhammadiyah Malang. Malang.

Widyastuti, N., dan Donowati, T. 2001. Peran Beberapa Zat Pengatur Tumbuh Tanaman Pada Kultur In Vitro. Jurnal Sains dan Teknologi Indonesia.

Yulia V. Chalenko., Mikhail Yu. Cherednichenko. 2017. In Vitro Introduktion and Cultivation. Of Aquatic Plant Alternanthera reinickii. Briq.

Yustina. 2003. Kultur Jaringan Cara Memperbanyak Tanaman Secara Efisien. Jakarta. Agromedia Pustaka 